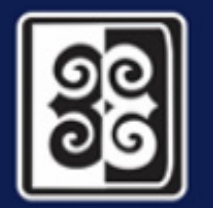 \\ INSTITUTE OF AFRICAN STUDIES UNIVERSITY OF GHANA
}

Contemporary Journal of African Studies 2019; 6 (1): 114-137

https://dx.doi.org/10.4314/contjas.v6i1.7

ISSN 2343-6530

(C) 2019 The Author(s)

Open Access article distributed under the terms of the

Creative Commons License [CC BY-NC-ND 4.0]

http://creativecommons.org/licenses/by-nc-nd/4.0

\section{Re-fashioning African Studies in an information technology driven world for Africa's transformation}

\section{Joseph Octavius Akolgo}

Phd Candidate, Institute of African Studies, University of Ghana Author's email: octaviusakolgo@gmail.com

\begin{abstract}
The African Studies programme, launched in the University of Ghana by Ghana's first president, was for "students to know and understand their roots, inherited past traditions, norms and lore (and to) re-define the African personality" and the "inculcation of time honoured African values of truthfulness, humanness, rectitude and honour ... and ultimately ensure a more just and orderly African society" Sackey (2014:225). These and other principles constitute some of the cardinal goals of the programme in both public and private universities in Ghana. Considering tertiary education as both a public and private enterprise, this paper seeks to enrich the discourse on African Studies by taking a retrospection of the subject and investigated university students' perceptions of the discipline among public and privately funded spheres. Adopting a qualitative approach, the paper interviewed students on the relevance of the discipline in a contemporary information technology driven world. The outcome of such interrogation was that African Studies is even more relevant in the era of globalization than it might have been in immediate post independent Africa. It concludes by unraveling how the discipline can be re-fashioned for Africa's transformation.
\end{abstract}

Keywords: African Studies, Africa's transformation, private universities, public universities, information technology driven world 


\title{
Re-fashioning African Studies in an Information Technology Driven World for Africa's Transformation
}

\author{
Joseph Octavius Akolgo
}

\begin{abstract}
The African Studies programme, launched in the University of Ghana by Ghana's first president, was for "students to know and understand their roots, inherited past traditions, norms and lore (and to) re-define the African personality" and the "inculcation of time honoured African values of truthfulness, humanness, rectitude and honour ...and ultimately ensure a more just and orderly African society" Sackey (2014:225). These and other principles constitute some of the cardinal goals of the programme in both public and private universities in Ghana. Considering tertiary education as both a public and private enterprise, this paper seeks to enrich the discourse on African Studies by taking a retrospection of the subject and investigated university students' perceptions of the discipline among public and privately funded spheres. Adopting a qualitative approach, the paper interviewed students on the relevance of the discipline in a contemporary information technology driven world. The outcome of such interrogation was that African Studies is even more relevant in the era of globalization than it might have been in immediate post independent Africa. It concludes by unraveling how the discipline can be re-fashioned for Africa's transformation.
\end{abstract}

Keywords: African Studies, Africa's transformation, private universities, public universities, information technology driven world

\section{Résumé}

Le programme d'Etudes Africaines, lancé à l'University of Ghana par le Premier Président du Ghana, visait à permettre aux «étudiants de connaître et de comprendre leurs racines, leurs traditions, normes et coutumes héritées du passé (et de) redéfinir la personnalité africaine», à permettre l'«inculcation de valeurs africaines traditionnelles de vérité, d'humanité, de rectitude et d'honneur... et à assurer ultérieurement une société africaine plus juste et ordonnée » Sackey (2014: 225). Ces principes et d'autres constituent certains des objectifs cardinaux du programme dans les universités publiques et privées du Ghana. Tout en considérant l'enseignement tertiaire comme une entreprise à la fois publique et privée, cet article cherche à enrichir le discours sur le programme d'Etudes Africaines en considérant le sujet en rétrospective et, ce, sur la base des enquêtes réalisés sur les perceptions des étudiants universitaires à l'égard de la discipline parmi les domaines financés par les fonds publics et privés. En adoptant une approche qualitative, l'article a interrogé des étudiants sur la pertinence de la discipline dans un monde contemporain axé sur la technologie de l'information. Selon les résultats de cette enquête, le programme d'Etudes Africaines est voire plus pertinent à l'ère de la mondialisation par rapport à la période ayant immédiatement suivi les indépendances en Afrique. Il conclut en décrivant comment la discipline peut être reconçue pour encourager la transformation de l'Afrique.

Mots-clés: études africaines, transformation de l'Afrique, universités privées, universités publiques, monde axé sur la technologie de l'information

https://dx.doi.org/10.4314/contjas.v6i1.7

Joseph Octavius Akolgo (octaviusakolgo@gmail.com) is a PhD candidate at the Institute of African Studies at the University of Ghana. He holds MPhil in African Studies and BA (Hons.) in Political Science and Theatre Arts from UG, Legon. He teaches African Studies at the View Valley University - Techiman Campus and tutors at Alliance Francaise Accra, both on part time basis. His research interest is in Youth, Rural Livelihoods, Land and issues of Development. His goal is to develop a professional career in academia, using research, teaching and public service to effect change in the lives of individuals and communities. 
The function of education is to teach one to think intensively and to think critically. Intelligence plus character - that is the goal of true education. - Martin Luther King, Jr.

\section{Introduction}

Education is the most powerful weapon which can be used to change the world said Nelson Mandela inspirationally. This powerful weapon is most often directed towards the young, who are often regarded as 'tomorrow's leaders'; logically, because the future and continuity of any animal category depends on its young ones. The decisiveness of education for the preservation of lives of members and the maintenance of the social structure in any society has been has similarly emphasized by Rodney (1972).

Hence, the kinds of knowledge education offer African youth is critical as it is important to the society in general. One wonders whether the education given the youth is inimical to the advancement of African ideals and values on the one hand, or whether it supports, promotes and consolidates non-African ideals and values, on the other. How education reflects values embraced by a group of people is also very crucial to development of communities of all kinds. It is the importance of the values to a given society that it has been argued that "education is not just the inculcation of facts as knowledge but a set of values that in turn appraise the knowledge being acquired" Nyamnjoh (2004:162). Thus, when the values are unsuitable for progress, "the knowledge acquired is rendered irrelevant and becomes merely cosmetic" (ibid). Education as a value enriching mechanism is critical to the kinds of knowledge needed to socialize the young. In the context of Africa, African centred knowledge would aptly meet this requirement.

Unquestionably, one of the key areas of study which is a fulcrum for African centred knowledge production is African Studies. Naturally, therefore, The 2nd Kwame Nkrumah Pan-African Intellectual \& Cultural Festival conference sought "to examine and critically investigate the role of African centred education and knowledge production for shaping the development agenda." Obviously African Studies would help students appreciate values which Nyamnjoh (2004) not only advocates but project same values introduced by post independent African universities.

Ghana's first president, Kwame Nkrumah had conceived the value of African centred education many decades ago as he had foreseen the relevance of knowledge production in Africa's transformation achievable through African Studies specifically, and education, generally. Therefore, in launching the African Studies programme in the University of Ghana in 1963, he advocated unambiguously for "students to know and understand their roots, inherited past traditions, norms and lore (and to) re-define the African personality" Sackey (2014: 225). Students were also admonished to embrace the "inculcation of time honoured African values of truthfulness, 
humanness, rectitude and honour (as well as) redefine youth immorality and indiscipline and ultimately ensure a more just and orderly African society" (ibid). These and other tenets constitute some of the purposes of the African Studies programme in universities in Ghana. This paper is, therefore, about Re-fashioning African Studies in an Information Technology Driven World for Africa's Transformation.

The paper seeks to answer the following questions: What has been the aim of African Studies from its inception after the Second World War and, also, as envisioned by Kwame Nkrumah? In the midst of highly privatized tertiary educational system and IT driven world, what are students' perceptions of African Studies? How should African Studies be refashioned in an information technology driven world for Africa's transformation? It is the intention of the paper to enrich the discourse on how African Studies should be refashioned to counteract the forces of "domination" and marginalization" in a highly globalized and information technology driven world.

\section{Methodology}

The study population was drawn from one public and three private universities, two of which were faith-based and the other a secular one. The main reason was to find out how the religious or foundational philosophy of the respective institutions could affect the perceptions of students of the discipline. The sample was taken from the University of Ghana, Valley View University, Islamic University College, Ajinringano, East Legon and Ashesi University, Brekusu near Aburi, in the Eastern Region.

The rationale for picking these institutions was manifold: firstly it was for convenience and cost effectiveness as they were within the researcher's reach. Secondly, in Ghana, the private sector has relatively lately become a funder of tertiary education as it is essentially considered "as a private good, a commodity to be bought and sold in an artificially constructed education market driven by the forces of supply and demand" Kelsey (1998:52). Although operating under strictly market principles, private universities are enjoined by the National Accreditation Board to have African Studies as a compulsory course on their curriculum. The addition of private institutions was to satisfy the public-private dichotomy.

Another consideration was for the purpose of achieving a good mix of religious and secular balance since the tertiary educational scene has become a highly competitive zone of varieties of products. The field is a panorama of all kinds of institutions "that are public and private; secular and religious; comprehensive and specialized; large and small; transnational and parochial; research intensive and vocational... and other defining social markers..." Zeleza (2009: 111). 
Hence in selecting the sample, this variegated and multi-dimensional educational landscape needed to be seriously considered so as to ensure that all 'blocs' were catered for. This position solidly rests on a perception that African Studies is a non-employable area. Sackey (2014) reveals that the "public has ridiculed African Studies" and argue that "students are expected "to learn "proper" disciplines that would fetch them employment after studies" and not remain liabilities on parents and the society at large (Sackey, 2014 : 253). Students therefore pursue Business-related and other courses as these are perceived to be employable programmes, hence the need to find out how all students' see African Studies irrespective of status as public-private student or course affiliation.

The main reason for stating the distinction between fee-paying and non-fee-paying students is to find out whether one's status a fee paying or non-fee paying could have any effects on how they perceive African studies. This very necessary as there are preferences for courses that are classified as "proper", with African Studies not favourably placed on that list. It was also to assess how the institutions organize the African studies programme as that organization could play a role in determining students' perception.

Participants were purposively sampled not necessarily by reason of 'specialist or in-depth knowledge' of the subject but on the basis of fulfilling the various categories of students described above. A qualitative approach was used to allow students freely respond to the research questions on the subject and share their personal perspectives without restrictions. Semistructured interview guide was designed on a 'teaser' into African Studies on what students' response was when they heard of "Africa or Africans". Interviews were conducted with four students from Ashesi University, six from Valley View University (three from Oyibi and three from Campus) and four from Islamic University College. Informal discussions were also held with UGRC 220 two tutorial groups, made up of thirteen and eleven members respectively, of the University of Ghana, ${ }^{1}$ on the subject. Data was collected between November 2016 and March 2017.

The reason for the choice of number of respondents from various universities was for two reasons. Firstly, it was largely determined by the function of financial resource limitation, to facilitate travelling to the institutions for many days, ${ }^{2}$ and time constraints, largely, on the part of the respondents. Appointments were made with many students from each

\footnotetext{
${ }^{1}$ This was when the research began the experiential learning project, a requirement of the PhD programme. This was from November 2016 until I presented the experiential learning report in April 2017. The students were sometimes in groups as they waited for their Teaching Assistant

${ }^{2}$ I traveled to Ashei on three different occasions, the first to make enquiries and appointments. I visited the campus on two more occasion. The road was not motorable and this increased the cost of travelling to campus. It was similar for the other institutions. The students, did not equally have enough time to interact fully with the researcher and thus was limited to the numbers. Later there was the need to visit the Techiman Campus because they have large numbers of sandwich teachers who are mostly teachers. The cost therefore restricted the choice of numbers.
} 
university, however, the respective numbers listed faithfully honoured the appointments. Secondly, the numbers provided per institution adequately supplied responses that met the expectation of the researcher on the issues being researched. Even though more students were interviewed from each of the universities, no new information was added to the themes of the research instruments, not previously given by those students. Thus a point of saturation was reached for the research (Crewell, 2012).

The paper has three sections. The first part is devoted to a review of literature, the aim of which is to address the goals of African Studies as an academic discipline. The second discusses the perceptions of African Studies by private and public tertiary students of the four universities. The final section attempts to suggest how African studies may/should be refashioned in an information technology driven world for Africa's transformation.

\section{Review of Literature}

Historically, African Studies developed outside Africa, not within it, and as a study of Africa, but not by Africans (Mamdani, 1998). The contact and study of Africa has its genesis in the fifteenth century, when Europeans began to explore the world and engage in studies of "primitive" societies out of curiosity but hardly related to rigorous scientific research. ${ }^{3}$ African Studies in its more contemporary origins are tied to post 1945, in the overall context of the onset of the process of decolonization and the rise of the East-West Cold War (Olukoshi, 2006; Melber 2009, UNESCO Courier, 1967). The aim for embarking on African Studies from precolonial to post-colonial epochs are not obvious but knowledge production and diversity of its uses are reasonable and noble goals for one to be involved in the venture.

\section{Colonial Era}

Prior to colonialism, Europe had trade relations with Africa including the obnoxious Trans-Atlantic slave trade. Shortly before Africa was formally partitioned, "a new interest" emerged which spurred Europeans to exceed the trade courtesies they enjoyed by directly mingling in the socio-economic life of Africans. This strategy was used to learn more about the peoples and resources available in the interior of the continent. They then determined which crops was to be given production priority. Missionaries also proselytized Africans to Christianity (Ajaye, 1989). At this juncture, there was no explicitly stated goal for Europeans learning about Africa neither was the study classically situated in the academic realm.

The aim of studying Africa at the dawn of, and during colonialism was, logically, to systematically replace African attitudes, tastes, education system, institutions and belief systems among others, with those of the

\footnotetext{
${ }^{3}$ See content.inflibnet.ac.in/data-server/eacharya...304/2/.../304-2-ET-V1-S
} 
European systems and institutions. A speech by Sir Babington Macaulay to the British parliament in 1835, after touring and learning about India provides a lead. The imperial politician argued that to be able to break a nation with a strong cultural and spiritual heritage, strategically, one needed to replace her educational system. He contended then that if the colonized "think that all that is foreign and English is good and greater than their own they will lose their self-esteem, their national culture and they will become what we want them, a truly dominated nation" (https://robertlindsay.wordpress.com/2012/12/01/ lord-macaulays-speech-to-british-parliament-1835/).

This scheme apparently worked effectively in many parts of Africa as even today many Africans, including some Ghanaians, have a strong taste for all things Western (Falola 2003: 91) and adherents of African traditional religions are outnumbered by those of non-African beliefs (GSS, 2013:62). Although this writer has no knowledge of existing colonial official policy document backing this statement, it makes sense to believe that colonial acculturation policy came to anchor on the thinking of Sir Macaulay.

\section{Objectives of African Studies in the Post-colonial Era}

After World War II, African Studies was employed chiefly as a medium for understanding Africa and its people. This was not for epistemological purposes from the Western perspective. African Studies, as de Haan (2010: 99) has described, was "colluded in an all-encompassing civilization mission where it was necessary to know and understand Africa better." This stance is ideologically and racially motivated and considered "a cultural product of the West ...perceived as politically passive". It therefore does not offer significantly meaningful contribution to the study of the continent Abrahamsen (2003: 190)

The ideological partiality of postcolonial theory is heavily criticized by Afrocentric writers. Mlambo (2006) argues that "western science, capitalism and social science and other (forms of) knowledge and practices not only lead to the domination of the African continent by the West," but has also led to Africa's marginalization in the world in terms of economic development including the continent's capacity to participate fully in the global knowledge community" ( $p, 161)$. Contrary views maintain that African Studies is meant to produce knowledge about Africa since it is least studied and is similarly associated with undergraduate education generally (Hodder-Williams, 1986)

The postcolonial goal was primarily "to decolonize" the discipline. African intelligentsia rediscovered and rewrote their peoples' histories and humanity previously seized and denied by Europe (Zelesa, 2009:116). An audacious effort was made to elevate discourses in African Studies by producing "alternative, sometimes radical, narratives of African history 
and development... (and) meant "to challenge received wisdom about the continent's past" (Olukoshi, 2009: 537). African Studies was to counteract the misrepresentation of western scholarship that portrays Africa and its people as an "other", a "unique phenomenon", "a dark continent", "continent whose history only began with the arrival of the European" (ibid). The goal was to counteract the denigration and to unveil "the African personality" as an equal global citizen.

\section{Nkrumah's Vision of African Studies ${ }^{4}$}

Nkrumah's vision and expectation of African Studies was embedded in his inaugural speech of the Institute of African Studies of the University of Ghana on 25th October 1963 which comprehensively lays out the objectives and scope of African Studies. The IAS and academics were admonished "to study Africa, in the widest possible sense ... in all its complexity and diversity, and its underlying unity" as well as "...the history, culture and institutions, languages and arts ... in new African-centred ways". The discipline is to "reassess and assert the glories and achievements of our African past and inspire our generation, and succeeding generations, with a vision of a better future". The youth can only be inspired by what has been achieved, and learn from the mistakes made by earlier generations which must serve as a guiding principle for shaping a progressive future.

African Studies should inculcate a sense of certain core values in students, with morality being key. Morality may embrace those values that are acceptable in our communities, for instance being each other's keeper, respect for the elderly, hard work, trustworthiness etc. Gyekye (2013) explains that "the morality established and maintained by our culture was a social morality, the kind of ethic that emphasizes concern for the wellbeing of every member of the society" (p.173). This morality is embedded in the social ethic of the society and requires that "each member of the community acknowledges common values, obligations and understandings and each person feels commitments to the community expressed through desire and willingness to advance its interests" (ibid).

Nkrumah saw tertiary education as the "kind ... which will produce devoted men and women with imagination and ideas, who, by their life and actions, can inspire people to look forward to a great future". Nkrumah probably was referring to the Ghanaian and the African situation, in general. He urged that "our aim must be to create a society that is not static but dynamic, a society in which equal opportunities are assured for all" and educational administrators must "remember that as the aims and needs of our society change ... our educational institutions must be adjusted and adapted to reflect

\footnotetext{
$\overline{4}$ These quotes are taken from Nkrumah's inaugural speech, titled "The African Genius," at the opening of the Institute of African Studies
} 
this change." University curricula must adjust to changing societal needs.

To Nkrumah, education was meant to make a person more open-minded with critical judgment skills as it "consists not only in the sum of what a man knows, or the skill with which he can put this to his own advantage" but... (s/he) "Must also be measured in terms of the soundness of his judgment of people and things, and in his power to understand and appreciate the needs of his fellow men, and to be of service to them". Additionally, education ought to produce people who must have empathy and sympathy and should genuinely make an effort to ensure community-wide welfare. The educated person should be so sensitive to the conditions around them that their chief endeavour would be to improve these conditions for the good of all. The goal of education, as outlined by Nkrumah, is very apt for any society but more so for the communal African society. His idea of education, particularly at the tertiary level, is one that reflects the ubuntu philosophy - I am because you are and you are because I am. Nkrumah expected that beneficiaries of education would use its fruits for the communal good.

It may further be expounded that Nkrumah's exhortation was to build on the general aim of African 'traditional' education which is "based on the socio-cultural and economic features shared by the various communities" (Nsamenang and Tchombe, 2011: 24). Traditional education's main aims, among others, have been "to create unity and consensus in society... to inculcate feelings of group supremacy and communal living and to prepare the young for adult roles and status" (ibid). Tertiary education, in this scheme of things, should be a continuum of this life process among members of the society, irrespective of one's level of western educational attainment.

In summary, Nkrumah envisage African Studies to be an emancipatory mission for those bound by "mental slavery" of the western educational system. Very critical in Nkrumah's vision of African Studies is for the student "to be deeply rooted in his culture and exhibit high moral standards acceptable in the African community" (emphasis added). Another objective that cannot be overlooked is that African Studies is to equip the student to be aware of how colonialism studied African institutions and this knowledge should prepare and empower the student intellectually to deflect the maneuverings of neocolonialism and other forms of domination.

\section{Perceptions of Tertiary Students of African Studies}

The rationale for attempting to capture the aims of African Studies as envisioned by Nkrumah is to evaluate whether or not what he saw many years ago to be the role of African-centred education through African Studies has changed with globalization and information technology. As will be discussed below, the findings among students of all categories described in the methodology section reveal a general unanimity about the relevance of African Studies. 
Before proceeding with the above endeavour, it is necessary to define 'Perception' as used in the context of the paper. It has been argued that "Our contact with the world is through perception" (Wade 2005: vii). Perception is considered a process by which individuals organize and interpret their sensory impressions in order to give meaning to their environment. People's behaviour is based on their perception of what reality is. It is also seen as a complex phenomenon that provides an input higher-order processes such as making a choice (Hoffman et al, 2015). Perception therefore plays a role in our life choices and influences attitudes towards the undertakings of an individual. The term is not used in an exclusively philosophical sense, but has been given its everyday meaning; thus the way something (in this case African Studies) is regarded, understood or interpreted. The Oxford Advance Learner's Dictionary meaning of perception as "an idea, a belief or an image you have as a result of how you see or understand something" is also significant in use of the term in this paper

The interest in this project began when the writer started organizing tutorials in the University of Ghana and later taught African Studies at the Valley View University-Techiman Campus. The question arose, "if you hear [the words] Africa or Africans, what comes to your mind?" This question became a standard 'entry point' of the African Studies tutorials and lectures and was used to assess what students' perception of the continent and its people were.

\section{Analysis of the Results}

The responses varied but were mostly negative. Featuring was the view "black man with black sense" or the idea that the African cannot do anything positive or that Africans think negatively of themselves and their continent. Another perspective was that Africans have a "pull him down" (PhD) attitude, interpreted to mean that individuals within some African communities are not inspired or enthused to see one of their own progressing or "doing well" in the area of business or any endeavour of life. Rather, detractors make efforts to "pull him (such a person down)". Some respondents claim that such negative efforts are normally advanced in the spiritual realm. In this situation, victims were pursued through detractors visiting spiritualists ("witch doctors") to drag the 'progressive person' down. This belief, though difficult to pursue empirically, persisted among most students who were interviewed. Others claimed that there could be smearing of the successful person's image by subtle or blatant negative propaganda such as spreading false information. Such negative propaganda could be crafted to suggest that the person's success is achieved through unorthodox means.

Related was the response of "black man with black sense" and "African mentality". The former was suggested to mean that some people did not have 
expectations of positive prospects for their neighbours. Respondents claimed that there are often scheming and machinations to undo each other, even if those involved were brothers or related by blood. The latter was not explained entirely differently. These statements could not be based on empirical examples as no specific communities were cited. The assertions more likely reflected discourses on the media landscape as such unsubstantiated allegations are often made on radio and television programmes and social media platforms.

Africans (leaders) are corrupt and power drunk," "Africa has bad or visionless leaders" and that some of these leaders use their ethnic groups to stay in power in perpetuity. Some students mentioned that "backwardness is the hallmark of Africa." Other views that are negatively perceived include beliefs and practices in witchcraft. Africa has a dependency syndrome or she has perpetual over reliance on Western countries. This response has mostly been a refrain. Others say Africa is a continent with resources but no skill and interest to develop them using our (Africans') own intelligence. Also Africans are people with negative cultural practices.

There were also positive responses that recurred with every year group. These included "Africa is a continent with rich culture and a lot of natural and human resources," "Africans are religious people who observe high morals," "Africa has a large population" (but this was not given any qualification), "Africa contributes a lot of raw materials to the world." "Africa has beautiful culture" and so on.

The unfavourable responses gave the impression that some Ghanaian tertiary students perceived their continent negatively prior to undertaking the mandatory African Studies course. I therefore decided to find out what students' perceptions, particularly, the relevance of African studies as a discipline, was after they had undertaken the lectures in the discipline.

Even though the idea was to find out students' perception about African Studies, the researcher allowed other opinions which bordered on their perceptions also about the continent. The analysis, based on the responses, have been classified under three themes namely Culture and History, Leadership and Governance and the African identity, and finally, Africa's contribution in the global community.

\section{Culture and History}

One striking response repeated throughout the research was students' surprise or shock when the question of "relevance" of African Studies was asked. It was as if the questioner was not from academia. This reaction emerged among both direct fee paying students, whether from public or private, and 'non-fee paying students'. Not only were the responses from participants emphatic

\footnotetext{
${ }^{5}$ Every tertiary student pays a fee of sort hence this category refers to students' whose fees are somewhat subsidized.
} 
about the relevance of African Studies but also positive of its centrality for the future of the youth of Ghana. A student from University of Ghana said:

We didn't know anything about Afro Studies initially and just thought we would use it to meet the requirement, but from the first three 'intro lectures', it is one of the most crucial courses on campus that can help to understand who we are as a people. It will help, we, the younger generations to know their past, help future leaders to know the sacrifices their forefathers made and the practice good democracy.

In the writer's days as an undergraduate student, African Studies was meant to satisfy the requirement for award of the degree by 'just' passing it. Some students did not attend African Students lectures until a few weeks or days to the examination. At a higher level, it is not uncommon to hear from some social science professors and lecturers who make demeaning remarks about the methodological approach of African Studies because it is perceived that qualitative method is not rigorous enough. This is often demoralizing, particularly because these kinds of comments are from persons who are supposed to be well informed and should be educating the ordinary person on the street.

Participants were of the view that African Studies to exposes students to the culture and history of Africa. The course was perceived to teach African culture and history which was important. A student from VVU-Tuchman Campus said:

African Studies is a tool for achieving tolerance to any culture in our society where one person will not look down on the culture of others. It makes learners know more about the cultures of others.

This response is significant in that there are misunderstandings and conflicts among people because of ignorance of each other's culture. Hence this response means that some students most probably understand the uniqueness of culture and would, all things being equal, respect each other's culture, especially since Ghana, like the rest of Africa, is multicultural. One would expect those who respond this way to respect the culture of a community s/ he is to serve in any capacity. Some participants also saw culture to be "the backbone of communities" while others saw it to be a source of identity. Even in the midst of globalization, it is culture that distinguishes one group from another. The response was summed up thus:

Everyone is equal in the world, so it is our dressing, the songs that we sing, our dances that will make us uniquely Ghanaian. When one watches the opening ceremony during the Olympics, you would normally identify each country by its dressing. It is also good to see 
Ghanaians in some traditional attire - usually kente. Some aspects of our culture can also bring us foreign exchange, so African Studies is very relevant in this respect.

Not all respondents wholeheartedly embraced the relevance of culture and African Studies. Students of theology and those with religious sympathies tended to perceived African Studies as projecting ideals that are not 'edifying to the soul' and therefore retrogressive in the spiritual sense. A Level four hundred Religious Studies student from a private university expresses this view:

In some situations, African culture does not promote ideals that edifies the soul. Some cultural practices in Ghana do not conform to the scriptural ways of worship. African Studies do not condemn such acts but seem to 'condone' such practices in the name of culture. How can such negative 'cultures' help develop the continent.

Though this argument is flawed, as outmoded cultural practices are not glorified in African Studies, very 'conservative' religious adherents hold such an opinion. Negative cultural practices were also highlighted and the perception of some participants was that students who had undertaken the course and understood the uniqueness of culture and how to negotiate transformation of outmoded cultural practices should help influence the modifying of negative ones. Teachers who work in the rural communities with NGOs and other advocacy groups were called upon to execute this task. Belief in witchcraft, female genital mutilation, bad widowhood rites, and negative exotic marriage practices such as leverage marriages, child marriages, marriage to deities like the Trokosi ${ }^{6}$ system among others, were seen to be backward in the information technology world. Archaic cultural practices paint "a very ugly image of Ghana and Africa in the eyes of the rest of the world", a sandwich student observed. Education, (i.e. sensitization), was suggested to be the means to end most of these negative cultural practices and that students who had read African Studies were better positioned to help in that regard.

African Studies was perceived to be a subject that taught African History (incidentally, the past was perceived negatively) and governance systems: "Afro Studies helps us to have awareness about our past so as to guide us (to) establish good identities or personalities as Africans". The discourse relative to this point was that leadership has failed to learn from the mistakes of the African past.

\footnotetext{
${ }^{6}$ A participant mentioned this as an example in the Volta Region. The author does not know much about this system and is not in the position to declare it negative as most of the things said about it is from the media and NGOs. These groups might not give a holistic assessment of the practice. However, the media landscape presents Trokosi as a very retrogressive cultural practice which makes it possible for young girls to be engaged to deities. It is said the priests eventually have children with 'the children so betrothed to the deities.
} 
Other opinions bordered on a globalized system that dictated the pace and Africa could only trod along without choice, redering national political leadership particularly as 'obedient' followers.

\section{African Contribution to and in the Global Community}

The massive contribution of the continent's raw materials to the global economy was a matter of interest and disappointment to the students. The reality that most of the continent's raw materials are exported to the industrialized Western countries for processing serves as double loss for the continent and its youth. While most African leaders lament the lack of employment openings for the continent's youth, they are, at the same time, busily and unaccountably exporting youth employment opportunities to others. A student from the University of Ghana argued that it was not raw materials that were being exported, but employment prospects that were expended to the youth of industrialised countries to the detriment of the teeming youthful population of the continent. He contended that the "refusal" of African leaders to pursue a 'drastic' industrialization drive for the continent was self-enslavement and betrayal to the youth and other sections of the African society. Contributing raw material to global community, although positive, represents a negative contribution as it compromises Africa's youth employment and the continent's self-reliance.

One positive reflection of Africa in the global community that was highlighted was the exemplary leadership demonstrated by Kofi Annan as the former UN Secretary-General. Similar positive images of Africa is the contribution to global sports and entertainment by men and woman from the continent, both at home and abroad. The puzzle has always been why Africans within the continent are not as influential in the sports field as Africans who are in the diaspora. This similarly reflected in Africans who have contributed to inventions while outside the continent. The research revealed respondents' conclusious that there was the need to do a further research into why this situation exists beyond issues of sports infrastructure and academic facilities.

\section{Leadership and Governance}

These are very important issues to tertiary students who participated in my research. Most of the responses held that there is no future for the continent if leadership remains visionless, full of empty promises and divisiveness. A number of respondents expressed disdain for leaders who are ever and very ready to enrich family and friends and cronies as well as praise singers of leadership. One student remarked :

Our governance systems have problems continent-wide, there are problems with parties in power, there are problems with parties waiting 
for power. African Studies is perhaps the way out: if we the younger generations will take the course more seriously and attempt to put into practice some of the things suggested in writings in African Studies, and learn from the history of the great leaders of Africa there will be hope for our country.

Other respondents similarly expressed grave concerns about the absence of reliable electoral systems that could be insulated from manipulation of incumbent political parties. Other views on leadership and governance yearned for a situation where African countries could run elections without funding from external sources. This would reflect that the continent is truly independent and free from external or neocolonialist manipulation. The inability of African politicians to think and act 'independently' was because of the reliance on western countries to fund every project, including elections.

Another response relating to governance suggested African countries should have working institutions grounded on the rule of law. The media is pereceived as extremely partisan and unable to effectively serve its watchdog role. Most students gave examples of Ghana where, depending on the leanings of the media house, opinions are presented as facts, and "some media groups think for the public". Further, respondents charged that the raw facts are not presented to listeners or readers but rather conclusions or insinuations intended to bait or direct them, thus they are made to feel s/he cannot decide what the truth is but must be guided by the 'truth' as presented by the media house. The research participants thus concluded that the media was not very helpful in ensuring good governance because a vibrant and principled media is a recipe for good governance.

Some of the respondents were concerned about the battered image of Africa. These concerns centred on negative things about the continent such as being the hub of poverty, centre of ethnic conflicts, 'patrons' of corruption, victims of communicable diseases such as HIV/AIDS and others, and, in general, a continent of squalor. Others were also worried about racial abuse of the continent's sports personalities who have been denigrated, even on the field of play. Students perceive that in the globalized world, there is still the need for a positive African identity and African Studies helps one to understand why Africans have a battered/negative image, are stereotyped and grossly misrepresented either intentionally or through ignorance.

The fact that over the years nothing seems to be working positively for Africa was also expressed strongly. Issues such as low pace of advancement of liberal democracy which has been accepted as the medium of governance, unimpressive economic performance of African countries spanning time and space, violent conflicts and the springing of vigilant and terrorists groups, rising and unsolvable unemployment crisis among others are serious concerns 
for some students. Suggestions were made that solutions to some of these retrogressing developments could be found using African Studies lectures as platforms.

\section{Other Perceptions}

Some students, though in complete disagreement with the relevance of the area, expressed somewhat deviating opinions from the above. A female Accounting student from Valley View University commented as follows:

African Studies, is too bookish and you must be very interested in reading to enjoy it. Those of us who do calculations always do not have some of its elements in our course area. So when the lecturer leaves, the class, it becomes very difficult. It would have been good to have the course designed into some aspects of the courses we all pursue. It is difficult to identify African Studies in some courses.

Another observation made was related to courses with practical components offered by some universities. For instance, in University of Ghana, courses like Music and Dance Studies have their practical elements. A participant observed that even though African Studies is relevant, the practical aspects end with the course in the university campus after the student has written and passed the examination. The participant doubted the long term relevance of such electives, particularly after school when there are no notes or reading material to which one can refer.

The above observations may not be inappropriate as they may reemphasize the call that the university must adapt to the changing needs of society. For instance, how should certain Western modelled courses be designed in the African Studies programme to address such concerns are worth exploring. It is equally important to bring home to students that the field must not necessarily be designed to accommodate all courses but that such courses could also be designed using Afrocentric approaches which can address the concerns raised. There is also the need for methodological innovations in some of the electives taking into consideration how the students may make reference in future after school.

\section{What about employment?}

The likelihood that a course of study would ensure employment was also raised by some respondents as already hinted by Sackey (2014). A respondent who expressed no qualms about the relevance of African Studies to raise the consciousness of African values, morality and aspirations, as envisaged by Nkrumah was, however, pessimistic of the course's prospects of providing "rewarding employment". "Most of us are trying to have the degree because of getting a good job", he explained, "but African studies is like humanities 
and social science courses; I know most students who are from the humanities do not get fulfilling jobs". This concern is a concrete and realistic one. The current outcry of every parent and student in or out of the university currently, particularly in Ghana, is employment. A desperate mother in the South African movie, Sarafina, said her children "do not eat glory". Knowledge acquired from a course and its relevance remains 'fantasy and fairy tales' if the graduate remains jobless. As the film's character cited above inferred, the student would not eat, wear, and be accommodated by knowledge if that knowledge fails to earn him/her a decent job.

The employment question is not just about African Studies courses but the entire educational system and its connection to the needs of the economy of most African countries. Most of the universities are still fixated on course content while employers want resourceful graduates who are problem solvers. Hence, Nkrumah's admonition that the ever changing nature of "our society" required dynamic forward looking educational institutions that can keep pace with the rapidly changing society must be seriously considered. African Studies institutions and centres may also need to redesign courses of the discipline with objectives of traditional education in an information communication technology. Such an innovation would assuage uncertainties confronting students in relation to employment. Be that as it may, it must, however, be understood that "Not all university programmes are professional oriented" (Sackey, 2014: 260). There are professional as well as non- professional disciplines which are complementary. Some courses offer broad knowledge to advance and prepare students for life; African Studies is one such course and it could provide students solutions to the employment problem.

\section{Discipline not taken seriously}

A different perspective presented on the relevance of African Studies is the lack of seriousness on the part of some students. One student was clear on the relevance of the discipline but observed that some students in his institution "did not take the course serious"[sic]. In that university, courses in the discipline attracted one credit hour per semester. Students were unclear as to whether or not it was truly calculated as part of calculation of the overall cumulative grade point average (CGPA). The respondent stated that since students "believed that it was not calculated for our overall CGPA, nothing drastic will happen if they didn't take the courses serious"[sic]. The respondent also stated that they heard some time ago that the course was to be removed from the university's curriculum. This 'rumour' has lingered for some time and encouraged apathy and lack of commitment from some students. 
The discipline suffers similar fate in one of the sampled institutions ${ }^{7}$ but in a different form. In that institution, students read African Studies as an aspect of another course. ${ }^{8}$ While the university discussed in the first instance had clear courses and their codes for African Studies, the latter had none. The organization of African Studies in the format described, in the institution, is merely to fulfil the policy of African Studies being made compulsory by the National Council on Tertiary Education. The idea of submerging African Studies with other courses brings to mind the genesis of the discipline in the University of Ghana in the late 1940s. Professor Kofi Abrefa Busia had been appointed as a lecturer in African Studies tasked with developing progam". Confronted with lack of personnel and other problems the school faced, he converted African Studies to a Department of Sociology instead. Professor Busia is reported to have said "African Studies? We are all in Africa so studying Africa..." (Allman, 2013: 184, 185). This argument was later to be used by other liberal lecturers who contended that "since the university is an African university it presupposes that its orientation in every department should be automatically African" (Sackey, 2014: 251). While no evidence has been found to link some current private institutions to amalgamating and submerging African Studies to other courses akin to what manifested in the University of Ghana in the formative stage of the discipline, these institutions have apparently reactivated these historical antecedents.

Another observation made related to courses with practical components offered by some universities. For instance, in University of Ghana, courses like Music and Dance Studies have their practical elements. Thus, a 'power struggle' or 'feud' ensued between Eurocentric social science courses and African Studies as a discipline. "African Studies was ridiculed and dismissed as a legitimate academic pursuit" by some Western academicians and African liberalists academics (Sackey, 2014: 250). The course was thought undeserving of a place on the University of Ghana curriculum (Sackey, 2014: 250, 259). African Studies courses were designated dondology-studies in drumming and dancing - when the School of Performing Arts was hitherto an integral part of the Institute of African Studies. Some universities see the compulsory programme of study for all university students as being rammed down their throats by the National Council on Tertiary Education.

The irony in the instance of these institutions is that while fee paying students recognize the relevance and do not have concerns earning more credit hours from the courses of the discipline, it is the institutions that probably seek to maximize cost by either curtailing the number of credit hours or amalgamating it into different course areas just to fulfil the National Council

\footnotetext{
${ }^{7}$ These institutions in the sample would not be named for the reason it might dent their business image since they are private.
}

${ }^{8}$ This was as at the time of this project and it is unknown whether this would continue to be the case. 
Akolgo, J. O./ Re-fashioning African Studies in an Information Technology Driven World

on Tertiary Education policy. Some private institutions are only legally bound to run African Studies as a discipline and do not see it as necessary area for the pursuit of knowledge and an avenue for inculcating the youth with African values:

To equip students with indigenous knowledge of Ghana and Africa broadly defined to include inherited ideas, beliefs, values, legends, mythology, institutions and practices, science and technology. The goal is to nurture in the youth of Ghana and Africa the desire and the skills to fashion home-grown solutions to Africa's problems.

The overall controversy of these debates and lack of unanimity of Afrocentric epistemology of African Studies continues to be the reason for the discipline being ridiculed and students "not taking the course seriously".

\section{Evaluation of the responses}

The overall evaluation of the responses offered by students re-affirms the vision Nkrumah had about African Studies in his 1963 inaugural speech. African Studies institutes and centres have significant roles to play, but more importantly the universities themselves have to give the prominence to African Studies as it is the only course that teaches and acquaints the students with their African identities as well as their cultural roots. African Studies is even more important today than it was in the post-independence era because Africans have carved a niche in every sphere of life from the political to socio-economic, and from the scientific to technological, among others. It is therefore important that students are made aware of these developments that would ensure that they are not global spectators but see themselves as contributors to the wider human community.

\section{Refashioning African Studies for Africa's Transformation}

In suggesting how African Studies should be refashioned for Africa's transformation, it is worth satisfactorily answering the question "what is the rationale for African Studies in the postcolonial context?" (Olukoshi, 2006). Or better still, what is the rationale for African Studies in the ICT age? Is the discipline for image reconstruction, ideological rebuttals, cultural revolution, epistemological reasons etc? It is also important to take on board the kind of development that is being sought for in the transformation, as advocated by the Kwame Nkrumah intellectual conference. Would the development being pursued be at the benevolence and generosity of another, or a self-reliant one? Is political leadership sincere in the development agenda?

The emancipatory mission of African studies which Ghana's first President, Kwame Nkrumah, unambiguously and succinctly articulated when 
he urged the participants in 1963 to produce genuine knowledge about Africa through scientific and academic rigour to promote Africa's development and transformation in response to thematic concerns of the time is a parallel reason for revolutionizing African Studies and knowledge production to answer for a new mission and vision. What new mission is being embarked upon? In addressing the 'thing' African Studies ought to be doing, there is the need to take stock of why knowledge was produced in African Studies during colonialism and postcolonial epochs.

In a retrospective reflection, it has to be appreciated that knowledge production in African Studies has long been "extraverted, i.e. externally oriented, intended to meet the theoretical needs of our Western counterparts and answer the questions they pose" about Africa and Africans (Hountondji, 2009). In this sense, it may be laudable to suggest that the discipline should be 'domesticated'; thus African scholars should make African Studies 'an autonomous, self-reliant process of knowledge production and capitalization that enables us (as Africans) to answer our own questions and meet both the intellectual and the material needs of African societies", to borrow from Hountondji (2009).

A wider project of "knowing oneself in order to transform" is necessary for the development we seek. This "wider project" would then be that African scholars involved in African Studies should "develop first and foremost an Africa-based tradition of knowledge in all disciplines, a tradition where questions are initiated and research agendas set out directly or indirectly by African societies themselves" (ibid) to address questions and issues pertaining to the continent. This strategy would unearth African solutions to African problems and not repeat models from the West.

In the period immediately after independence, African Studies was concentrated on delineating Africa and espousing its values for the world to know us better. This agenda, though important, significantly led to the neglect of "intra-African cross-national learning." This situation has made mainstream African Studies constitute itself into a tool for others to master Africa (Olukoshi, 2006:539). In refashioning African Studies for Africa's transformation this trend has to change. The youth must be encouraged to learn about intra-African issues and cross fertilize ideas not only through attending conferences physically but by making effective use of information communication technology to interact directly. For instance, using Skype or video conferencing, why cannot students in the University of Ghana, University of Ibadan, University of South Africa, University of Cairo and University of West Indies discuss a common African problem/issue and proffer solutions to a commonly identified subject?

In an ICT driven world, social media can be and should be used 
effectively to link-up African youth from various parts of the world to engage in discourses that would promote socio-economic, political and other topical issues concerning Africans. As African youth in different parts of the world, they can categorise and share experiences such as their aspirations and fears, the opportunities and obstacles and how these can be achieved and surmounted respectively, etc. Using these media must, however, be managed innovatively by African Studies centres and institutes so as to avoid infiltration by radical fundamentalist groups that may use African youth to embark on unwanted social upheavals. These institutions should provide an academic framework to define the scope and ensure sanity of the discourses to guarantee intellectual benefits to the youth, as individuals, and to their communities.

To refashion African Studies for Africa's transformation in an ICT driven world, it would be appropriate to adopt critical thinking and problem solving approaches to African Studies. This strategy would be useful in tackling notorious subjects like corruption, over reliance on foreign aid, taste for foreign things, bad leadership, etc. Professors, senior scholars and others with experience, but not necessarily in academia, could fashion out a regulatory framework in which students are encouraged to employ critical thinking and creative ways of addressing these entrenched ills in African societies. Again ICT could be used for global outreach for contributions of ideas on shades of human endeavour from the African community.

In an information technology driven world it is more critical now than ever before to use documentaries and cinema/films to advantage. Africa's history should be re-interpreted and presented on Youtube and other streaming media heavily patronised by the youth for their comprehensive education on the historical achievements as well as the failures of the continent. These sketches can also be used as teasers to motivate students into reading the seminal works in African Studies. African Studies fashioned for an IT driven world would make it easier to reach African youth with intellectual information that would educate them about the realities of the continent's progress and failings, rather than relying on information from other sources that may not be authentic or that could be misrepresentations.

Another area that may help in refashioning African studies for Africa's reconstruction and transformation is reading material on African Studies. There are more readings on Africa outside the continent than within it. Most people do not find Africanists writings on Africa until they enter higher institutions of learning, which does not make the situation easier because critical books on Africa and Africans are scarce. African Studies centres and institutes should intensify efforts to increase accessibility of reading material which is beyond the reach of most African youth. These should be put on the worldwide net so that students can access this information easily and without drudgery. 
Another way of refashioning African studies for Africa's transformation is to move to the lower ladder of the educational system and institute the teaching/learning of African Studies at all levels of education, from primary to university level with suitable subjects for the various stages. Catch them young, as it is often said, must be an implementable aphorism. One of the ways of refashioning African Studies is to begin from colleges of education where Africa's teachers are trained to take responsibility of the upbringing of younger children through Afrocentric epistemology. It appears that Western epistemology extols virtues of the West that downplay and overshadow African-centred values. For instance, some students were unacquainted and unfamiliar with African 'indigenous' science and technology activities in their communities. It was only when things such as herbal preparation, blacksmithing, brewing, spinning cotton wool into thread, etc were pointed out to them did they begin to have a deeper appreciation of science and technology in their communities. Most Ghanaians, and I dare suggest, African tertiary students lack fundamental knowledge about their countries and their continent, Africa.

\section{Conclusion}

Students perceive African Studies to be relevant in contemporary educational curriculum of tertiary institutions, irrespective of their status as either a fee paying students or public sponsored students. The religious or philosophical foundation of the students' institution played no role in how African Studies was perceived. Concerns raised by students with respect to certain courses need a thorough scrutiny and appropriate action to meet the expectation of a majority of students.

Africa's reconstruction and transformation is hinged on African Studies. There must be commitments from African states, particularly financial and infrastructural, to facilitate the programme as a field of study. Educational policy makers must be flexible but Africanists -institutions and individuals- need to push them to act more responsively. Bureaucrats, like political leadership, seem visionless and contradictory, hence the need for constant pressure to be applied. Institutions like the National Accreditation Board and the National Council for Tertiary Education among others need very strong collaboration and 'orientation' from the Institute of African Studies, Legon. It is observed that personnel in these institutions have probably not read the mandate given by Ghana's president to the Institute. This is because there are some tertiary institutions in Ghana that do not have typical African Studies courses but use other liberal studies courses as proxies. Supervision is lax and tutors who are not certificated in African Studies are the people handling African Studies courses. It is only collaboration and advocacy by 
the Institute of African Studies, Legon and departments of African Studies in other universities that can turn things around for the better.

African youth need to be taught the true history of Africa, without distortions. It is not wrong to be defensive with those who misrepresent, stereotype or denigrate the African on the one hand. On the other, it is appropriate to be candid about African history and the continent's current situation, and present both to the student. It will help the youth decipher the truth from the falsehood. As the Jamaican reggae star Robert Nester Marley has urged in his lyrics: we must therefore "open our eyes and look within", by knowing ourselves in order to transform. I am mindful that these proposals will not altogether be easy but where there is a will there is a way. Africa and its youth will be the winners ultimately. 


\section{References}

Abrahamsen, R. (2003). African Studies and the Postcolonial Challenge. African Affairs, Vol. 102, No. 407, 189-210.

Allman, J. (2013). Kwame Nkrumah, African Studies, and the Politics of Knowledge Production in the Black Star of Africa. The International Journal of African Historical Studies, , Vol. 46, No. 2 (2013), 181-203.

Alpers, E. A. (2002). What Is African Studies? Some Reflections, Identifying New Directions for African Studies. African Issues, Vol. 30, No. 2, 11-18.

Cresswell, J. W. (2012). Educational Research, Planning, Conducting and Evaluating Quantitative and Qualitative Research. 501 Boylston Street, Boston: Pearson Education, Inc.

de Haan, L. J. (2010). Perspectives on African Studies and Development in Sub-Saharan/Perspektiven der Afrikaforschung und der Entwicklung im subsaharischen Afrika. Africa Spectrum, Vol. 45, No. 1 (2010), pp. 95-116.

Dike, O. K. (1967, June). The Scientific Study of Africa's History. The UNESCO Courier, 9-13.

Falola, T. (2003). Power of African Cultures. Rochester: University of Rochester Press.

Ghana Statistical Service (2013). 2010 Population \& Housing Census National Analytical Report. Accra: Government of Ghana, Accra.

Gyekye, K. ((2013)). Philosophy, Culture and Vision: African Perspectives. Accra: Sub-Saharan Publishers.

Hodder-Williams, R. (1986). African Studies: Back to the Future. African Affairs, Vol. 85, No. 341 (Oct., 1986), 593-604.

Hountondji, P. J. (2009). Knowledge of Africa, Knowledge by Africans:

Two Perspectives on African Studies. RCCS Annual Review [Online]

URL: http://rccsar.revues.org/174; DOI: 10.4000/rccsar.174.

J, W. N. (2005). Perception and Illusion: Historical Perspectives. Springer

Science + Business Media, Inc.

Kelsey, J. (1998). Privatizing the Universities. Journal of Law and Society,

Transformative Visions of Legal Education, Vol. 25, No. 1, (Mar., 1998), 51-70.

Mamdani, M. (1998, April 22nd, Wednesday). Is African Studies to be turned into a new home for Bantu education at UCT? Text of remarks at the Seminar on the Africa Core of the Foundation Course for the Faculty of Social Sciences and Humanities, University of Cape Town,. Cape Town, South Africa. 
Melber, H. ((2009)). The Relevance of African Studies. Stichproben. Wiener Zeitschrift für kritische Afrikastudien Nr.16/2009, 9, 183-200.

Mlambo, A. S. ( 2006). Western Social Sciences 1 and Africa: The

Domination and Marginalization of a Continent African .

Sociological Review, 10, (1), , 2006, 161-179.

Nkrumah, K. (1963, October 25th). The African Genius: Speech by Dr.

Kwame Nkrumah, President of Ghana at the opening of the Institute of African Studies at the University of Ghana, Legon, Accra, Ghana. Nsamenang, A. B. (2011). Handbook of African Educational Theories and Practices: A Generative Teacher Education Curriculum. Bamenda, North West Region (Cameroon): Human Development Resource Centre (HDRC).

Nyamnjoh, F. B. (2004). A Relevant Education for African DevelopmentSome Epistemological Considerations. Africa Development, Vol. XXIX, No. 1, 2004, 161-184.

Olukoshi, A. (2006). African Scholars and African Studies. Development in Practice, Vol. 16, No. 6, 533-544.

Rodney, W. (1973). How Europe Underdeveloped Africa. Washington, D. C: Howard University Press.

Sackey, B. M. (2014). African Studies: Evolution, Challenges, and Prospects. In J. A.-E. Samuel Agyei-Mensah, Changing Perspectives (pp. 239-262). Springer Dordrecht Heidelberg New York London: Springer Science+Business Media Dordrecht.

Zelaza, P. T. (2009). African Studies and Universities since Independence. Transition, No. 101, Looking Ahead (2009), 110-135. 